\title{
CIGARETTE SALES PROMOTION PATTERN AND SMOKING BEHAVIOR OF SELLERS IN MULAWARMAN UNIVERSITY, SAMARINDA
}

\author{
Riza Hayati Ifroh ${ }^{1}$, Iwan M. Ramdan ${ }^{2}$, Vivi Filia Elvira ${ }^{3}$, Rahmi Susanti ${ }^{4}$, \\ Reny Noviasty ${ }^{5}$, Ika Wulan Sari ${ }^{1}$ \\ ${ }^{1}$ Health Promotion Department, Faculty of Public Health Universitas Mulawarman \\ ${ }^{2}$ Occupational Health and Safety Department, Faculty of Public Health Universitas Mulawarman \\ ${ }^{3}$ Environmental Health Department, Faculty of Public Health Universitas Mulawarman \\ ${ }^{4}$ Biostatistics and Population Department, Faculty of Public Health Universitas Mulawarman \\ ${ }^{5}$ Nutrition Department, Faculty of Public Health Universitas Mulawarman
}

\begin{abstract}
Mulawarman University has the largest number of students in Kalimantan (37,000). That number has the potential to be smokers (23.6\%) supported by the lack of smoke-free areas in all faculties and the high circulation of cigarettes through the retail franchises in campus area. The purpose of this study was to determine the dominant factors influencing cigarette sales of cadgers in Mulawarman University and to analyze the correlation between cigarette sales figures, types or brands of cigarettes, attributes and types of cigarette promotion media, knowledge and smoking behavior of cigarettes seller. The design of this study is quantitative research. The sampling technique in this study population of 60 units/sellers in the main campus, Mulawarman University. Statistical analysis on ordinal data using the Spearman analysis test, nominal data using contingency coefficients and ratio data using Pearson analysis. The study showed that the average cigarette sales per day are 311 cigarettes with the range (min-max) 19-1760 cigarettes per day, the type of cigarette promotion media is (55\%) banners. The variables have correlation to cigarette sales are types of cigarette sales places ( $p=0.047, R=-0.257)$; the use of media promotion display $(p=0.002, R=0.390)$ and profits from selling cigarettes in rupiah nominal $(p=0.000, R=0.557)$. This study concludes that the profit of selling cigarettes and media promotion displays significantly related to the circulation of cigarettes on campus as of increasing regulation of non-smoking areas at the maximum is needed.
\end{abstract}

Keywords: Sales promotion, cigarettes, smoking behavior

\section{POLA PROMOSI PENJUALAN ROKOK DAN PERILAKU MEROKOK PEDAGANG DI UNIVERSITAS MULAWARMAN SAMARINDA}

\begin{abstract}
ABSTRAK
Universitas Mulawarman merupakan perguruan tinggi dengan jumlah mahasiswa terbesar di Kalimantan (37.000). Jumlah tersebut berpotensi sebagai perokok $(23,6 \%)$ didukung dengan belum terealisasikannya kawasan tanpa rokok di seluruh fakultas serta peredaran rokok pada pedagang kaki lima maupun ritel waralaba di wilayah kampus. Tujuan dari penelitian ini adalah adalah mengetahui faktor yang dominan mempengaruhi penjualan rokok di kios pedagang kaki lima lingkungan mahasiswa berdasarkan analisis hubungan pada variabel angka penjualan rokok, jenis atau merk rokok, atribut dan jenis media promosi rokok, pengetahuan dan perilaku merokok pedagang kaki lima. Desain penelitian ini adalah penelitian kuantitatif dengan total sampel sebesar 60 unit/pedagang. Analisis statistik pada data ordinal menggunakan uji analisis spearman, data nominal menggunakan coefisien kontingensi dan data rasio menggunakan analisis pearson. Hasil penelitian ini adalah rata-rata penjualan rokok perhari adalah 311 batang rokok dengan penjualan rokok tertinggi adalah 1760 batang, dan jenis rokok yang memiliki tingkat penjualan tertinggi adalah rokok putih, selain itu jenis media promosi rokok pada tempat dagang rokok di lingkungan Kampus Utama Universitas Mulawarman adalah (55\%) spanduk dan (15\%) promotion display. Adapun variabel yang memiliki hubungan secara statistik terhadap penjualan rokok adalah jenis tempat penjualan rokok $(\mathrm{p}=0.047$, $\mathrm{R}=-0.257$ ); penggunaan media promotion display ( $\mathrm{p}=0.002, \mathrm{R}=0.390)$ dan keuntungan penjualan rokok dalam nominal rupiah $(\mathrm{p}=0.000, \mathrm{R}=0.557$ ). keuntungan dari penjualan rokok dan tampilan promosi media
\end{abstract}

\footnotetext{
${ }^{1}$ Correspondece Address: Riza Hayati Ifroh Jl. Sambaliung,Gunung Kelua Campus, Faculty of Public Health Building, Mulawaman University, 75117 Email: rizahayatiifroh@gmail.com
} 
secara signifikan berhubungan dengan peredaran rokok di kampus sehingga meningkatkan pengaturan area bebas rokok secara maksimal menjadi salah satu hal yang dibutuhkan.

Kata Kunci: Promosi penjualan, rokok, perilaku merokok

\section{INTRODUCTION}

The ASEAN Tobacco Control Report (2015) showed that $26.6 \%$ of the population of Southeast Asia are smokers, Indonesia is the one country with the highest number of cigarette consumption in the Southeast Asia region $(50.68 \%)$ who classified as active adult smokers. The prevalence of smoking in Indonesia percentage is $67.4 \%$ in men and $4.5 \%$ in women with age classifications above 15 years. ${ }^{1}$ Indonesian Health Basic Research in 2013 showed that the average number of cigarettes consumed by smokers in Indonesia is 12.3 cigarettes per day with the proportion most active smokers every day at the age of $30-34$ years by $33.4 \% .^{2,3}$

The factors that can influence the purchasing power of people's cigarettes are the mass media's exposure to promoting cigarette products with all forms of creativity and media strategies for cigarette producers as well as other factors, namely knowledge, attitudes and perceptions about smoking, exposure to mass media, lifestyle, and the environment and access towards cigarette sales. ${ }^{2,4}$ Cigarettes easily items to find and legally circulate throughout Indonesia. Some locations for selling cigarette products are from roadside stalls to supermarkets where people observe the affordability of prices and places of purchase. People prefer to buy cigarette products on the side of the road, because they can buy retail and close to home, campus or workplace. ${ }^{2}$ At present the tobacco industry is aggressively marketing cigarettes to young people and making them a marketing subject. $^{5}$

In the process of circulation of cigarettes in the community, the cigarette seller both producers and distributors of cigarettes have marketing and promotion strategies to increase the selling power of cigarettes. Promotional, distribution and price aspects simultaneously influence cigarette purchasing decisions. Cigarette traffickers put up media and displays of cigarette products that are displayed lined up in a shop window or cigarette sales place to make it easier for consumers to see the types of products. ${ }^{2,6}$ advertisements aimed directly at consumers at the point of sale are known to influence tobacco use behavior. ${ }^{7}$

The high exposure to cigarette advertisements on television, newspapers, magazines, pamphlets, uncontrolled advertising banners has caused anxiety for the public due to increased access to information and negative exposure to cigarettes in the environment of children and adolescents for example in educational environments such as schools and colleges. ${ }^{8}$ Students are the main target of the cigarette industry, where $70 \%$ of total smokers in Indonesia, start smoking before the age of 19 years and groups of students are included in this group because the average student who is active in college is between the ages of 17-22 years. ${ }^{9,10}$

The research on factors level of cigarette sales is the active role of cigarette sellers. Sales promotion girl in persuasive communication to consumers. ${ }^{11}$ It is also known the characteristics of the location of cigarette sales, motivation and selling the power of wholesalers, retail as well as the cigarette promotion media, increase cigarette purchases by the public and young people groups. ${ }^{12}$

Mulawarman University is one of the universities in Samarinda, East Kalimantan with an active smoker (22.3\%). ${ }^{13}$ Mulawarman University is a university with the largest number of students in Kalimantan, reaching more than 37,000 people. This number has the potential to be a smoker supported by the non-realization of non- 
smoking areas in all faculties and the high circulation of cigarettes through the mobilization of street vendors and retail franchises around the campus.

Some research on the smoking behavior of students and the effectiveness of the smoking area in the campus area has available, ${ }^{2,12,14}$ but the specific components of the impact of the mass media, advertising attributes promotion of cigarettes and the factors that affect the sale of cigarettes in the campus area is limited. Based on this, an indepth study needs to be carried out to obtain accurate data-based assumptions to provide more comprehensive information in analyzing the dominant factors affecting cigarette sales at the Mulawarman University student street stalls. The purpose of this study is to analyze variables (cigarette sales figures, types or brands of cigarettes, types of media, sales profits, subjective perceptions, knowledge and smoking behavior of traders) in influencing the circulation of cigarettes on the Main Campus of Mulawarman University.

\section{METHOD}

This research was conduct by quantitative design with a survey approach. The location of this research is in the main campus area of Mulawarman University, Gunung Kelua, Samarinda Ulu, Samarinda. The location of the research point is in a radius of $1.05 \mathrm{~km}$ around the campus with the consideration that the education area is a nonsmoking area, based on Peraturan Bersama Menteri Kesehatan dan Menteri Dalam Negeri No.188/Menkes/PB/I/2011No.7Tahun $2011 .^{15}$

The location of the study was selected based on the criteria of access and driveways Mulawarman, jalan Pramuka, Perjuangan, Gelatik simpang Belatuk, M.Yamin, Suwandi and the entire region and faculty at the University Main Campus Mulawarman. The sample in this study were all street vendors who entered within $3.35(\mathrm{~km})$ radius of the main campus area of Mulawarman University. Sample selection is limited by criteria. Inclusion criteria were (1) Street vendors including large retailers and small retailers; (2) available in the study location when the interview is conducted; (3) Communicate well; (4) Selling cigarette products; (5) Have a cigarette promotion media. The exclusion criteria were street vendors in the main campus area of Mulawarman University who unsell cigarettes. The sampling technique in this study population of 60 units/sellers in main campus in Mulawarman University.

\section{RESULTS}

\section{Demographic Characteristics}

The characteristics of cigarette sellers in the Mulawarman University main campus are bellow:

Table 1.Characteristics of Cigarette Sellers in Mulawarman University by Age and Income

\begin{tabular}{cccc}
\hline Variables & Mean & Min & Max \\
\hline Age & 40.23 & 16 & 70 \\
Income & $2.314 .166,-$ & $100.000,-$ & $15.000 .000,-$ \\
\hline
\end{tabular}


Table 2.Characteristics of Cigarette Sellers in Mulawarman University

\begin{tabular}{lcc}
\hline \multicolumn{1}{c}{ Variables } & $\mathbf{n = 6 0}$ & Percentage \\
\hline Gender & & \\
Male & 20 & 33.3 \\
$\quad$ Female & 40 & 66.7 \\
Cultural Tribe & 19 & 31.7 \\
Bugis & 9 & 15 \\
Banjar & 25 & 41.7 \\
Jawa & 1 & 1.7 \\
Sunda & 6 & 10 \\
Others & & \\
Education Level & 5 & 8.3 \\
Uncompleted primary school & 15 & 25 \\
Primary school completed & 9 & 15 \\
Secondary school completed & 28 & 46.7 \\
High school completed & 3 & 5 \\
Collage or University & & \\
\hline
\end{tabular}

Based on table 1 and 2, the average age of respondents in this study were 40 years with the lowest age of cigarettes were 16 years, in addition, it is known that the average

\section{Cigarette Sales}

The following are the results of the frequency distribution of cigarette sales income from the monthly selling was 2,314,166,- (Rp) with the lowest nominal income was $100,000,-(\mathrm{Rp})$ and the highest was $15,000,000,-(\mathrm{Rp})$.

variables at the main campus of Mulawarman University:

Table 3.Cigarette Sales In Mulawarman University

\begin{tabular}{lcccc}
\hline \multicolumn{1}{c}{ Variables } & Mean/Median & Modus & Min & Max \\
\hline Cigarette sales per day (bar) & 311.67 & 160 & 19 & 1760 \\
Cigarette sales profit per day (Rp) & $300.000,-$ & $10.000,-$ & $0,-$ & $2.400 .000,-$ \\
\hline
\end{tabular}

Sellers who consider selling cigarettes provide the profits amounted to $91.7 \%$, with average daily revenues from cigarette sales is
227,691,- (Rp) and the biggest income per day is $2,400,000,-(\mathrm{Rp})$

Table 4.Cigarette Sales In Mulawarman University

\begin{tabular}{lcc}
\hline Variables & $\mathbf{n = 6 0}$ & Percentage \\
\hline Type of Sales Place & 6 & \\
Store & 46 & 10 \\
Shop & 3 & 76.7 \\
Restaurant/cafe & 2 & 5 \\
Kiosk & 3 & 3.3 \\
$\quad$ Street vendor & 44 & 3 \\
The ownership of Sales Place & 13 & 73.3 \\
Own property & 3 & 21.7 \\
Rent & & 5 \\
Others & 60 & 100 \\
Type of Cigarette & 0 & 0 \\
White & 59 & 98.3 \\
Hand-rolled & & \\
Kretek & 48 & 80 \\
Selling Duration & 8 & 13.33 \\
Less than 1 year & 4 & 6.7 \\
1 2 years & & \\
More than 2 years & 1 & 1.7 \\
Perception of Profit & 4 & 6.7 \\
No & 55 & 91.7 \\
Undecided & &
\end{tabular}


The highest type of selling place is a stall at $76.7 \%$, with ownership of the location of trade is self-owned at $73.3 \%$. In the type of cigarettes, $100 \%$ white cigarette selling and 98.3\% kretek to sell.

\section{Types of Cigarette Promotion Media}

The following are the types of outdoor media available at cigarette shops in the main campus area of Mulawarman University.

Table 5. Media Promotion and Marketing of Cigarettes at the Entrance of Mulawarman University

\begin{tabular}{lcc}
\hline \multicolumn{1}{c}{ Variables } & n $=\mathbf{6 0}$ & Percentages \\
\hline Banner & 33 & 55 \\
Poster & 9 & 5 \\
Neon Box & 0 & 0 \\
Wall Painting & 0 & 0 \\
Flyers & 8 & 13.3 \\
Promotion Display & 9 & 15 \\
Billboard & 8 & 13.3 \\
\hline
\end{tabular}

Based on table 3 , there are types of cigarette promotion media that available at selling locations in the main campus of Mulawarman University, with 33 stalls (55\%), 8 flyers attached to the sale place wall $(13.3 \%)$, promotion displays as many as 9 trade places $(15 \%)$ and cigarette billboards at 8 sale places $(13.3 \%)$.

\section{The Knowledge of Smoking Dangers}

The description of the knowledge of cigarette sellers in Mulawarman University is as follow

Table 6. The Overview of Cigarette Sellers' Knowledge about the Dangers of Smoking

\begin{tabular}{|c|c|c|c|c|}
\hline \multirow{2}{*}{ Aspek Pengetahuan } & \multicolumn{2}{|c|}{ Correct } & \multicolumn{2}{|c|}{ False } \\
\hline & $\mathbf{n}$ & $\%$ & $\mathbf{n}$ & $\%$ \\
\hline Smoking causes deteriorating health & 56 & 93.3 & 4 & 6.7 \\
\hline Smoking causes a stroke & 43 & 71.7 & 17 & 28.3 \\
\hline Smoking causes a heart attack & 54 & 90 & 6 & 10 \\
\hline Smoking causes lung cancer & 54 & 90 & 6 & 10 \\
\hline Smoking causes bronchitis & 41 & 68.3 & 19 & 31.7 \\
\hline Smoking causes asthma & 53 & 88.3 & 7 & 11.7 \\
\hline Smoking causes ulcers & 32 & 53.3 & 28 & 46.7 \\
\hline Smoking causes impotence & 38 & 63.3 & 22 & 36.7 \\
\hline Smoking does not transmit HIV-AIDS & 40 & 66.7 & 20 & 33.3 \\
\hline Smoking causes pregnancy disorders & 49 & 81.7 & 11 & 18.3 \\
\hline All cigarettes sold are dangerous & 51 & 85 & 9 & 15 \\
\hline The main chemical substance of cigarettes is poison & 46 & 76.7 & 14 & 23.3 \\
\hline Cigarettes cause addiction & 51 & 85 & 9 & 15 \\
\hline Smoking also endangers the health of passive smokers & 35 & 58.3 & 25 & 41.7 \\
\hline Secondhand smoke is dangerous for passive smokers & 47 & 78.3 & 13 & 21.7 \\
\hline The average score of knowladge (min-max) & \multicolumn{4}{|c|}{$76.67 \quad(0.00-93.33)$} \\
\hline
\end{tabular}

Based on the table illustrating the knowledge of the dangers of smoking, that the lowest knowledge is about the concept of smoking can cause ulcers $(53.3 \%)$ and the highest knowledge items are causes deteriorating health conditions $(93.3 \%)$. The average score of knowledge is 76.67 with the lowest score is 0.00 and the highest is 93.33 .

\section{Smoking behavior of Cigarettes Sellers in Mulawarman University Area}

The description of the smoking behavior of cigarettes sellers in kiosks or street stalls around Mulawarman University in table 7. 
Table 7. Seller Smoking Behavior at Mulawarman University

\begin{tabular}{|c|c|c|}
\hline Variable & $\mathrm{n}=60$ & $\%$ \\
\hline \multicolumn{3}{|l|}{ Smoking Status } \\
\hline Non-smoker & 50 & 83.4 \\
\hline Daily smoker & 5 & 8.3 \\
\hline Occasional smoker & 2 & 3.3 \\
\hline Quit smoker & 3 & 5 \\
\hline \multicolumn{3}{|l|}{ Type of Cigarretes } \\
\hline White & 4 & 57.1 \\
\hline Kretek & 2 & 28.6 \\
\hline Both & 1 & 14.3 \\
\hline \multicolumn{3}{|l|}{ Smoking Area } \\
\hline Inside the house & 1 & 14.3 \\
\hline Outside the house & 2 & 28.6 \\
\hline Both & 4 & 57.1 \\
\hline \multicolumn{3}{|l|}{ Primarily Smoke } \\
\hline$<15$ years old & 2 & 28.6 \\
\hline $15-16$ years old & 2 & 28.6 \\
\hline 17 - 19 years old & 1 & 14.3 \\
\hline$\geq 20$ years old & 2 & 28.6 \\
\hline \multicolumn{3}{|c|}{ The Average Cigarette Consumed } \\
\hline $5-9$ bars & 4 & 57.1 \\
\hline $10-14$ bars & 1 & 14.3 \\
\hline $15-24$ bars & 1 & 14.3 \\
\hline$\geq 25$ bars & 1 & 14.3 \\
\hline
\end{tabular}

Based on table 7, it is known that there are 7 respondents who smoke and 3 respondents have quit smoking status. Based on seven respondents with smoking status, they tend to consume white cigarettes, which is $57.1 \%$ and as many as $57.1 \%$ of respondents smoke inside and outside the home. The first age of smoking is $28.6 \%$ explains each less than 15 to 16 years and more than 20 years and above.
The number of cigarettes consumed by respondents $57.1 \%$ spends $5-9$ cigarettes per day.

\section{The Affecting Factors of Cigarette Sales}

The correlation analysis to determine the relationship between cigarette sales with the factors will describe below:

Table 8. The Correlation Analysis

\begin{tabular}{lccc}
\hline \multicolumn{1}{c}{ Variable } & & Cigarretes Sales & \\
\cline { 2 - 4 } & & P-value & Correlation \\
\hline Demography Characteristic & & & \\
Age & 0.403 & 0.110 & - \\
Gender & 0.944 & 0.009 & - \\
Tribe & 0.702 & 0.050 & + \\
Education Level & 0.593 & 0.070 & + \\
Profit Perception & 0.101 & 0.214 & - \\
Type of Sale & & & + \\
Place of Sales & $\mathbf{0 . 0 4 7}$ & $\mathbf{0 . 2 5 7}$ & - \\
The Ownership & 0.590 & 0.071 & + \\
Sale Duration & 0.758 & 0.041 & + \\
Type of Promotion Media & & & + \\
Banner & 0.278 & 0.142 & + \\
Poster & 0.898 & 0.017 & - \\
Flyers & 0.948 & 0.009 & + \\
Promotion Display & $\mathbf{0 . 0 0 2}$ & $\mathbf{0 . 3 9 0}$ & + \\
Billboard & 0.983 & 0.003 & - \\
Knowladge & 0.164 & 0.182 & + \\
The Selling Profit (Rp) & $\mathbf{0 . 0 0 0}$ & $\mathbf{0 . 5 5 7}$ & + \\
Smoking Behaviour & & & + \\
Smoking status & 0.450 & 0.100 & \\
Type of Cigarrates & 0.350 & 0.418 & \\
\hline
\end{tabular}


Based on the statistical test results in Table 6, known that the type of cigarette sales place has a weak negative correlation (-) with a coefficient value $(\mathrm{R}=0.257)$ and the significance value is $(\mathrm{p}=0.047)$, this explains that the type of place of trade has a place the relationship to the sales of cigarette traders, in addition it is known that the use of promotion displays at cigarette trade locations significantly $(\mathrm{p}=0.002)$ is one of the factors that influence the sales of cigarette traders with a moderate (moderate) strength correlation, namely the coefficient $(\mathrm{R}=0.390)$ with direction positive (+), it can be concluded that the multiple types of outdoor media promotion display used will increase the cigarette sales in trade place.

Based on the table above, information is also obtained that there is a significant relationship $(\mathrm{p}=0,000)$ between sales and sales profits obtained by traders with a correlation of 0.557 or can be said to be a relationship with moderate strength (moderate) with a positive direction $(+)$ so interpreted if the sale of cigarettes increases, the seller's profits also increase. The profit of the seller is influenced by the sales of the cigarettes themselves, cigarette traders would receive the profits from the sales that are increasing every day.

\section{DISCUSSION}

Increased sales of cigarettes both retail and non-retail, contribute to increase number of active smokers, besides the existence of cigarette promotion media provides information that accesses to cigarettes is getting easier. ${ }^{12}$ This is supported based on the results of research that obtained exposure to cigarette promotion media on outdoor media types, namely banners $(55 \%)$, posters $(5 \%)$, flyers $(13.3 \%)$, promotion displays $(15 \%)$ and billboards $(13.3 \%)$ located in the sales location at a radius of $1.05 \mathrm{~km}$ from the outer fence of the campus area.

Dunn dan Barnan ${ }^{4}$ explains that advertising is a form of non-personal communication activities that are conveyed through the media by paying for the space used to convey persuasive messages to consumers by companies, non-commercial institutions, or interested individuals. Based on this target of cigarette sales, it is easier for students in the campus environment to access cigarettes for consumption. It is seen that the characteristics of cigarette consumers in the campus environment are $(68.3 \%)$ are students and $(90 \%)$ are male adults, although based on Peraturan Bersama Menteri Kesehatan dan Menteri Dalam Negeri No. 188/Menkes/PB/I/2011 No.7(2011), nonsmoking area is public area where declared prohibited from engaging in smoking, or producing, selling, advertising, promoting and or promoting tobacco products in education area. ${ }^{15,16}$

Smoking promotional efforts are increasingly demanding innovative health workers to apply media health promotion competitive with current cigarette advertising. ${ }^{17}$ The function of cigarette advertising is as a means to introduce cigarette products to the public, which ultimately impacts increasing sales of cigarette products. ${ }^{2}$ The impact on students considers cigarette advertisements and exposure to information will be normally and smoking behavior attached to them in learning activities and daily social activity. ${ }^{18}$

In this research, it is known that the factors that influence cigarette sales are the use of cigarette display promotion $(\mathrm{p}=0.002)$, based on Prasetyo, Ristiyanti and John, that cigarette product displays are clearly displayed in a row in a storefront or other long store media, making it easier for research subjects to see the types of cigarette products sold. ${ }^{2}$ In general, marketers rely heavily on the function of consumer vision in the marketing process. Various forms of advertising that are used, product packaging, store design, and display on the storefront are all intended to provide stimulation to the eyes of consumers. ${ }^{19}$ Public expectations for a product 
can be viewed on the display or trade performance this case following the display of promotion on the research that the seller uses the media to attract consumers to buy cigarettes. ${ }^{14,20}$

Another factor that also affects the sale of cigarettes in the main campus environment of Mulawarman University is the profit gained by traders when selling cigarettes. Based on the results, known that there were $(91.7 \%)$ of respondents consider that sell cigarettes provide an advantage in trade and hesitation $(6.7 \%)$. The Reality in the economic life of society, ${ }^{6}$ cigarettes are not only popular by adults but also by teenagers and even children. Harsh conditions these teenagers can quickly become dependent on cigarettes, and they will be more like cigarettes. Every place must sell cigarettes from various brands, ranging from the cheapest to the most expensive. Many factors influence people to take up smoking, that is because of the need, family, relationships, living environment, etc. ${ }^{21}$ Based on the impact on the environment and health of students, universities need to spend optimal resources on preventing the use and distribution of cigarettes. ${ }^{22,23}$

The consumer decision-making process is influenced by internal factors such as personal factors (lifestyle, work, personality, age, and life cycle stages), psychological factors, and external factors such as products, prices, places and promotions), ${ }^{12,24}$ social factors (reference groups and family), cultural factors 18. The danger of cigarette consumption is about $90 \%$ of lung cancer, estimated that 1 in 10 moderate smokers and 1 in 5 heavy smokers will die from lung cancer. ${ }^{14}$ Smoking damage blood vessels and nicotine substances contained in cigarettes will narrow the arteries, thereby reducing blood flow and blood pressure, one of them to the penis. If someone has experienced impotence, it can be an early warning that smoking has damaged other areas of the body.

Circulation of cigarettes is one of the common problems in order to reduce the number of active smokers, especially among college students, which is one of the educational settings. Based on Peraturan Bersama Menteri Kesehatan dan Menteri Dalam Negeri No.188/Menkes/PB/I/2011 No. 7 (2011), non smoking area is public area where declared prohibited from smoking, or producing, selling, advertising, promotion and or promoting tobacco products, one of which is in the educational environment. ${ }^{14}$ Despite the efforts of policy-making current campus is very strict about the area do not smoke ${ }^{23}$, however, the environment just beyond the campus, the off-campus environment, typically has abundant tobacco marketing where products are heavily marketed at the point-of-sale, making them highly visible, available, and affordable. ${ }^{25,26}$

\section{CONCLUSION}

The dominant factors affecting cigarette sales in Mulawarman University are the location, which is accessible for student entry, selling cigarettes profits and the using of media promotion display which making it easier for the student to see the types of cigarette products. It is expected that the management of Mulawarman University can impose area free from tobacco (AFT) throughout Mulawarman University areas such as in Banggeris (Campus Building 1), Flores (Campus Building 2) and Pahlawan (Campus Building 3). It is also expected that cooperation in public service, as well as a Business Center Mulawarman can record and manage vendors on campus to reduce exposure to advertising or promotion of cigarettes at the University Mulawarman. 


\section{REFERENCES}

1. SEATCA. The ASEAN Tobacco Control Report. 2012.

2. Cahyo, K., Wigati, P. A. \& Shaluhiyah, Z. Rokok , Pola Pemasaran dan Perilaku Merokok Siswa SMA / Sederajat di Kota Semarang. Media Kesehat. Masy. Indones. 11, 75-84. 2012.

3. Badan Penelitian dan Pengembangan Kesehatan. Riset Kesehatan Dasar. Riset Kesehatan Dasar. 2013.

4. Alfan, B. Pengaruh terpaan iklan spanduk rokok bintang buana terhadap minat beli. Universitas Islam Negeri Sunan Kalijaga. 2010.

5. Fallin, A., Roditis, M. \& Glantz, S. Association of Campus Tobacco Policies With Secondhand Smoke Exposure, Intention to Smoke on Campus, and Attitudes About Outdoor Smoking Restrictions. Am. J. Public Health 105, 1098-1100. 2015.

6. Mandey, J. B. Promosi, Distribusi, Harga Pengaruhnya Terhadap Keputusan Pembelian Rokok Surya Promild. Promosi, Distribusi, Harga Pengaruhnya terhadap Keputusan Pembelian Rokok Surya Promild 1, 9. 2013.

7. Giovenco, D. P., Spillane, T. E. \& Delnevo, C. D. Predictive Validity of Tobacco Product Advertising and Retail Availability. Tobbaco. Regulation. Sci. 5, 440-446. 2017.

8. Barker, D. C., Schleicher, N. C., Ababseh, K., Johnson, T. O. \& Henriksen, L. ENDS retailers and marketing near university campuses with and without tobacco-free policies. Tob. Induc. Dis. 16, 1-11. 2018.

9. Wattimury, A. A. Profil Pengetahuan Mahasiswa Fakultas Farmasi Universitas Surabaya terhadap Bahaya Rokok. Jurnal Ilmiah Mahasiswa Universitas Surabaya 2, 1-14 (2013).
10. Qudri, A., A. Gani, I. \& Hasyim, S. Tanggung jawab pemerintah terhadap iklan rokok yang merugikan konsumen dalam sistem hukum positif. Jurnal Ilmu Hukum Pascasarjana. Univ. Syiah Kuala 4, 18-22. 2016.

11. Munawar, A. \& Hasan, I. Strategi Komunikasi SPG Rokok Lucky Strike Mild dalam Meningkatkan Omzet Penjualan PT. Bentoel Internasional Investama Perwakilan Banda Aceh. Jurnal Ilmiah Mahasiswa FISIP Unsyiah 2, 1-11. 2017.

12. Burton, S., Ludbrooke, M., Williams, K., Walsberger, S. C. \& Egger, S. To sell or not to sell: cigarette sales in alcohol-licenced premises. Tob. Control tobaccocontrol-2017-053944. 2017. doi:10.1136/tobaccocontrol2017-053944

13. Dinas Kesehatan Kalimantan Timur. Profil Kesehatan Kalimantan Timur Tahun 2015.

14. Fatonah, S. \& Amatiria, G. Kepatuhan Warga Terhadap Peraturan Kawasan Tanpa Rokok di Lampung Selatan. Jurnal Keperawatan 12, 149-154. 2017.

15. Menkes \& Mendagri. PBM Menkes dan Mendagri No. 188 dan No 7 ttg Pedoman Pelaksanaan Kawasan Tanpa Rokok .pdf. 2011.

16. Asmarandani, D. Kios Rokok di Wilayah Kaki Lima Studi Bentuk Fungsi Antropometri Ergonomi. in Seminar Nasional Pakar 1 111-116. 2018.

17. Buchanan, L., Kelly, B. \& Yeatman, $\mathrm{H}$. The Effects of Digital Marketing of Unhealthy Commodities on Young People: A Systematic Review. Nutrients 10, 1-19. 2018.

18. Artana, Bagus; Rai, N. Tingkat Ketergantungan Nikotin dan FaktorFaktor yang Mempengaruhi. Fakultas 
Kedokteran Udayana. 2009.

19. Dutra, L. M.; James Nonnemaker; Brian Bradfield; Nathaniel Taylor; Jamie Guillory; Ashley Feld; Annice Kim,. Antismoking Advertisements and Price Promotions and Their Association With the Urge to Smoke and Purchases in a Virtual Convenience Store: Randomized Experiment. J. Med. Internet Res. 21, 1-12. 2019.

20. Firdias, A. Pengaruh Fear Appeals terhadap Motivasi Membeli (Survei pada Perokok Remaja Usia 13 sampai 19 Tahun di Kota Malang). J. Adm. Bisnis 59, 68-73. 2018.

21. GYTS. Global Youth Tobacco Survey ( GYTS ) Indonesia Report, 2014.

22. Clemons, K., Putnam, J., Johnson, D. B. \& Kiger, A. Decreasing Campus Smoking with Punishments and Social Pressures. 1-24. 2018.

23. Fagan, M. J., Fitzgeorge, L. \& Smith, W. J. Smoking zones versus smokefree zones on Canadian post-secondary campuses: Which zone is more effective, adhered to and preferred? Tob. Prev. Cessat. 5, 0-7. 2019.

24. Kelso, C. The Social Expectations Theory and The Influence of The Mass Media. 2013.

25. Wagoner, K. G; Erin L. Sutfin; Eunyoung Y. Song; Jessica L; Kathleen L. Egan; Beth Reboussin; Beata Debinski; Mark Wolfson. Trends in point-of-sale tobacco marketing around college campuses: Opportunities for enhanced tobacco control efforts. J. Am. Coll. Heal. 66, 145-154. 2019.

26. Pacheco, C. M; Anthony Wellever; Niaman Nazir; Joseph Pacheco; Kelly Berryhil; babalola Faseru; Charles Barnes; Christine M. Daley; Won S. Choi. Clearing the air: American Indian tribal college students' exposure to second hand smoke \& attitudes towards smoke free campus policies. J. Am. Coll. Heal. 66, 133140. 2018. 